\title{
Geo-seismic model for petroleum plays an assessment of the Zamzama area, Southern Indus Basin, Pakistan
}

\author{
Muhammad Akram Qureshi ${ }^{1,2} \cdot$ Shahid Ghazi $^{1} \cdot$ Muhammad Riaz $^{3,4}$ (D) $\cdot$ Shakeel Ahmad ${ }^{1,2}$ (1)
}

Received: 15 September 2019 / Accepted: 9 November 2020 / Published online: 1 December 2020

(c) The Author(s) 2020

\begin{abstract}
Seismic as well as structural techniques were exploited to elucidate the subsurface structure of the Zamzama area that directly led to petroleum system. Zamzama gas field is located in the Kirthar Foredeep, southern Indus Basin, Pakistan. The current research is based on data scrutinized systematically through eight seismic lines (796-JH-01, 02, 03, 07, 10, GHPK-98A-32, 34 and 40) and three wells (Zamzama-02, 03 and 05) drilled in the Zamzama field. Seismic interpretation reveals that Tertiary and Cretaceous sequence is deformed by transpressive tectonics, and a reverse fault is located from 400 to $3400 \mathrm{~ms}$ deep on the vertical seismic section. The hanging wall moves up along the fault plane under the action of eastward directed stress as a result an extensive North-South oriented and eastward verging thrusted anticline is formed. Stratigraphically, area encompasses well-developed Mesozoic-Cenozoic sequence. The Late Cretaceous Pab Formation is well-known primary hydrocarbon reservoir capped by the shale of the Paleocene Ranikot Formation that acts as a regional seal rock. The Jurassic and Cretaceous shales of the Sember and Goru formations are substantiated as main source rocks. The execution and portrayal of seismic and subsurface geological data provide the clues that area contains appropriate petroleum play potential. Present study suggests a worthwhile regional geo-seismic model that might be significant for future exploration in the Kirther Foredeep and adjacent areas.
\end{abstract}

Keywords Seismic interpretation $\cdot$ Geo-seismic model $\cdot$ Petroleum system $\cdot$ Zamzama gas field

\section{Introduction}

Seismic data, its integration with wells and geological data are consistent tool for subsurface geological depiction (Moghal et al. 2007; Ghazi et al. 2014; Riaz et al. 2018, 2019; Abid et al. 2019, 2020). An integrated approach is crucial for petroleum exploration and subsurface interpretations. It assists in tracing the subsurface geological structures and establishing reliable correlations. A precise identification of the subsurface geological perspectives and

Muhammad Riaz

riazjass@yahoo.com

1 Institute of Geology, University of the Punjab, Lahore 54590, Pakistan

2 Oil and Gas Development Company Limited (OGDCL), Islamabad, Pakistan

3 Centre for Geographical Information System, University of the Punjab, Lahore 54590, Pakistan

4 Department of Earth Sciences, Abbottabad University of Science and Technology, Havelian 22500, Pakistan structures is vital for hydrocarbon probe, and it delivers a perception about the framework and structural styles of a basin. Furthermore, interplay between shortening and shear has imperative implications for location of traps and their preservation. These seismic and surface data along with site of hydrocarbon fields portray substantial clue that might be valuable for upcoming exploration in Kirther Foredeep and adjoining areas.

The Zamzama gas field was discovered in Sindh province, Pakistan, covering an area of around $120 \mathrm{~km}^{2}$ and ranked fourth major discovered gas field of Pakistan. Geologically, Zamzama gas field is located in the Kirther Foredeep, Southern Indus Basin, approximately $200 \mathrm{~km}$ North of Karachi and $8 \mathrm{~km}$ west of the existing Sui-Karachi pipeline (Fig. 1). The Bhit gas field lies to the southwest and the Kadanwari, Sawan and Miano fields to the northeast of Zamzama filed. The Zamzama gas field was first explored in late 1950s drilled Phulji-1 and Phulji-2 wells (Jackson et al. 2004), and target was oil bearing carbonates of the Tertiary strata. Both wells were ensued dry because, gas bearing the Cretaceous to Paleocene Pab and Khadro reservoir could not penetrated. 
Fig. 1 Tectonic map of Pakistan and the divisions of Indus Basin (modified after Kadri 1995).

The red rectangle shows the study area. The inset figure shows the complete Zamzama structure that comprises of hanging wall and footwall structures (modified after Jackson et al. 2004). The Zamzama East-1 separates the southern and northern strands of the main thrust

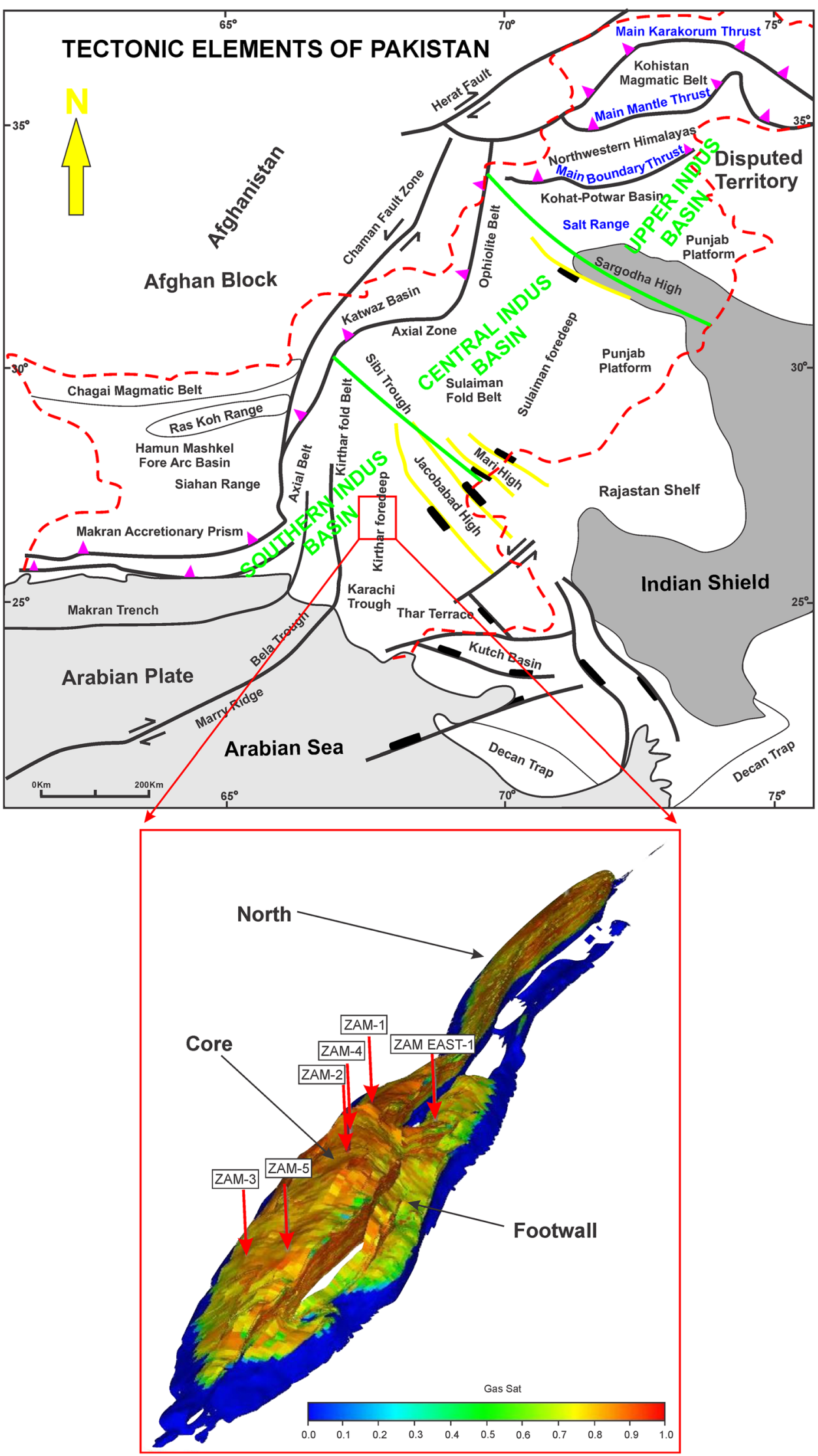


The inefficient results were reexamined with further seismic data (Quadri and Quadri 1998) and it was realized that Phulji-1 well was abandoned before few meters of the Pab reservoir. Later on the new research by various workers presented the overall structural style and the mechanics of deformation on the basis of integrated borehole and seismic data (Lillie et al. 1987; Jaume and Lillie 1988; Pennock et al. 1989; Treloar et al. 1992; Grelund et al. 2002). These innovative approaches were applied to Zamzama area and an exhaustive 2D seismic survey carried out about an area of $196 \mathrm{~km}$ that produced seven productive wells (Fig. 1). This paper reveals a comprehensive seismic model that evaluates petroleum play of the Zamzama Field primarily based on seismic data. It suggests a predictable model about substructure and surface stratigraphic architecture to explore future hydrocarbon reservoir.

\section{Methodology}

Subsurface data were employed to interpret the structure of the Zamzama area, which was obtained from land mark resources (LMKR) with the permission of Directorate General of Petroleum Concessions (DGPC), Ministry of Petroleum and Natural Resources, Islamabad, Pakistan. The data consist of three wells (Zamzama-02, 03, and 05) and eight seismic lines (796-JH-01, 02, 03, 07, 10, GHPK-98A-32, 34 and 40). These wells; Zamzama-02, Zamzama-03, and Zamzama- 05 are located at coordinates $26^{\circ} 42^{\prime} 17.13^{\prime \prime} 67^{\circ}$ $40^{\prime} 06.59^{\prime \prime}, 26^{\circ} 40^{\prime} 32.15^{\prime \prime} 67^{\circ} 39^{\prime} 16.25$, $^{\prime \prime}$ and $26^{\circ} 40^{\prime} 3.565^{\prime \prime}$ $67^{\circ} 40^{\prime} 14.20, "$ respectively. Seismic and well data were interpreted through Kingdom Suite software 8.2 (SMT). For structural as well as stratigraphic interpretation, six prominent reflectors (top of the Kirthar, Ghazij, Laki, Dunghan, $\mathrm{Pab}$ and Chiltan formations) were marked on the seismic lines which were correlated with well tops to confirm the position of marked reflectors and were allotted a specific age (Table 1). The Chiltan Formation was the most prominent horizon that helps to mark the faults. Furthermore, time contour map on top of the Pab Formation was generated to define the structural trend and deformation style.

\section{Geological setting}

Zamzama gas field lies in Kirthar Foredeep, Southern Indus Basin, which is separated from Central Indus basin at MarriKandhkot high (Kadri 1995; Kazmi and Abbasi 2008). The North-South oriented Kirthar Foredeep trough, subducted by the evolving Kirthar fold and thrust belt (Kazmi and Rana 1982; Kazmi and Jan 1997), developed in consequence of collision between Indian and Eurasian plates through Mio-Pliocene to recent times (Powell 1979). The study area corresponds to western part of Kirthar Foredeep, which is marked by Jacobabad Mari Kandhkot high toward its North and in South it has Hyderabad high and eastward limited by Nabisar Slop and Tharparkar high (Fig. 1).

During the Middle Jurassic (Bathonian/Callovian), the carbonates of the Chiltan Formation were deposited in a stable shelf platform followed by extension and consequent fault block rotation in the Late Jurassic (gentle) causing development of good reservoir within shoals/karstified area (Kemal 1991; Kadri 1995; Fig. 2). The Late Jurassic to Early Cretaceous Gondwana continued to split that caused the interior of the Indian Plate to be uplifted gently (Powell 1979), and ultimately the carbonate platform of the Middle Jurassic was replaced by shales and sandstones of shallow marine to deltaic settings (Sembar and Goru formations). Indo-Pak plate separated from Madagascar during the Late Cretaceous, and north-western part of the Indian plate passed over the Reunion hot spot, which resulted in eruption of the Deccan Trap (Khadro Formation) (Powell 1979). The said events are once again responsible for uplifting of the interior of the Indian plate and then replacement of carbonate platform by clastic sediments (Kazmi and Abbasi 2008; Shah 1977, 2009). Sinistral transpression developed by the Paleocene times along the western border of the Indus Basin that reached a point where inversion of the previously deposited sequences took place (Meissner and Rahman 1973; Kadri 1995). Meanwhile, deposition of carbonates resulted from comparatively calm conditions on the passive margin settings in North (Meissner and Rahman 1973; Shah 1977, 2009). The Eocene strata are perceived extensively, while mostly Oligocene sediments are missing. A thick pile of the Miocene to Recent molasses sediments
Table 1 Showing well tops which were correlated with seismic lines to mark the reflector for the interpretation of structure and stratigraphic succession

\begin{tabular}{llllll}
\hline Sr. no & Horizon & Depth $(\mathrm{m})$ & Velocity $(\mathrm{m} / \mathrm{sec})$ & Time $(\mathrm{sec})$ & Phase \\
\hline 1 & Top Kirthar & 2264 & 3000 & 1520 & (Peak +ve) \\
2 & Top Ghazij & 2440 & 3100 & 1580 & (Peak +ve) \\
3 & Top Laki & 2580 & 3150 & 1670 & (Peak +ve) \\
4 & Top Dunghan & 2975 & 3300 & 1840 & (Peak +ve) \\
5 & To Pab & 3712 & 3450 & 2150 & (Peak +ve) \\
6 & Top Chiltan & & & 2720 & (Peak +ve) \\
\hline
\end{tabular}




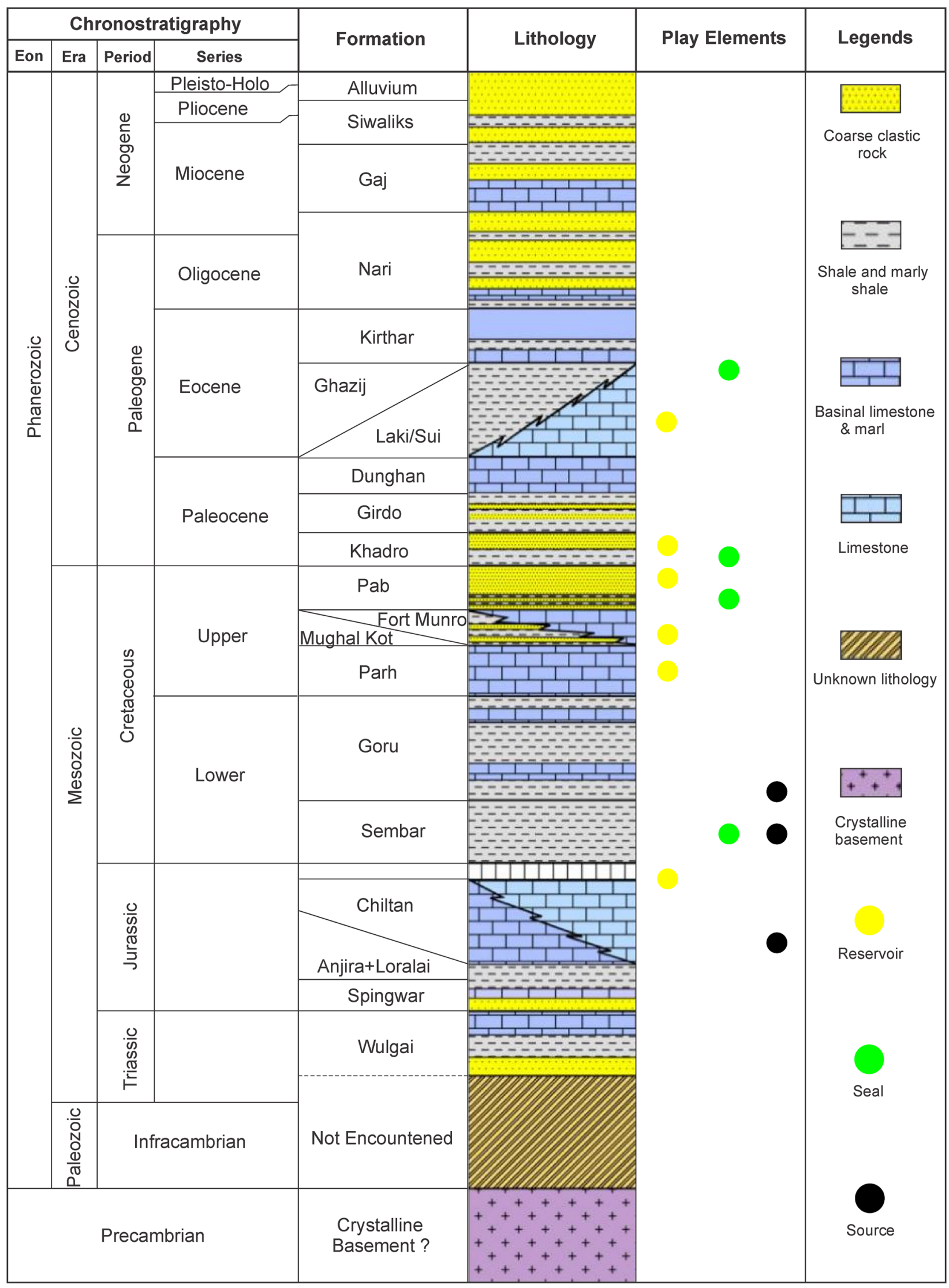

Fig. 2 Generalized stratigraphic succession of the Zamzama field, Southern Indus Basin, Pakistan (modified after Abbasi et al. 2016; Zafar et al. 2018) 
developed attributable to less influence of Himalayan Orogeny (Kazmi and Rana 1982; Kazmi and Jan 1997; Shah 1977, 2009; Fig. 2).

\section{Petroleum system}

The Miocene-Pliocene 15,000 m thick molasses sediments filled that extends North-South. Miocene to Recent (Siwalik) sediments dips gently and thickens westwards toward the axis of the Foredeep. The Eocene strata deposited but become thinner at Jacobabad-Khairpur high, further, Oligocene succession is absent here. The Mari, Khairpur, and Mazarani wells indicate the presence of the Paleocene and the absence of the Upper Cretaceous strata in the Kirthar Foredeep. Moreover, the Mesozoic and the Paleocene sequences also dip and thicken in the same direction as the foreland basin sequence. The central part of the Foredeep is covered by Quaternary alluvium. The greater thickness of sediments in the depression may provide good impact on the maturation to younger rocks, especially the Eocene oil shale (Siddiqui 1992; Siddiqui and Khan 1992; Kadri 1995). The western flank of the Foredeep was established as a petroleum province when commercial gas discovery was made in Upper Cretaceous sandstone (Pab Formation) (Kadri 1993, 1995; Fig. 3).

The Cretaceous shales of the Sembar and the Goru formations are considered as a main source rock in the Zamzama field. The Sembar Formation was deposited in marine environments over major part of Southern Indus Basin (Kazmi and Abbasi 2008; Shah 2009). Total organic carbon (TOC) of the Sembar Formation range from 0.5 to $3.5 \%$ and it has Type-III kerogen that generate gas (Kadri 1995). Additionally, regional maturity suggests that these values lie just above the main oil window, a fact validated by the Rock-Eval $\mathrm{T}$ max values which are in between $431{ }^{\circ} \mathrm{C}$ and $437{ }^{\circ} \mathrm{C}$ (Kemal 1991; Kadri 1995). However, the Goru Formation also reveals a source quality in the Talhar Shale. There are significant TOC contents, and pyrolysate yields of up to $3.58 \mathrm{~kg}$ Py/t rock (Kadri 1995). Regional maturity modeling and $\mathrm{T}$ max indicate the late mature stage for oil generation (Kemal 1991; Jamil et al. 2012). These evidences also suggest the presence of both oil-prone and gas-prone sediments within the Goru Formation. The Lower Goru Formation was deposited as a regionally extensive fluvio-deltaic system over the entire Southern Indus Basin that comprises terrestrial organic matter which is the main source of oil generation (Kemal 1991; Siddiqui 1992; Kadri 1995; Kazmi and Abbasi 2008; Jamil et al. 2012).

The upper Cretaceous Pab Formation mainly comprises of sandstone that act as reservoir. The formation is welldeveloped in the Kirthar Foldbelt, however, truncate in East of the Zamzama gas field. It forms an important reservoir unit in the West of the Kirthar area (Jackson et al. 2004). Previously it was not considered to represent a significant reservoir target although it is proven in study area (Zamzama gas field). Beside sandstone it also contains silty mudstones. The base of formation is easily defined in East, whereas in the West thick massive turbiditic sandstones of the Pab Formation make unconformable contact with basinal limestone of the Mughalkot Formation. Moreover, the typical sand-body geometry of progradational delta sequences is dependent to some degree on the relative dominance of fluvial versus wave/tide processes. Stream dominated deltas are typically elongate and lozenge shaped, while wave/ tide dominated deltas with a stronger "shoreface" character are elongate parallel to basin margins with a typical beachridge geometry (Blair and McPherson 1994; Reading 1996). Therefore, sandstones are interpreted as reservoirs of the Pab Formation in the Kirthar deltaic or deep marine turbidite fan.

$\mathrm{Pab}$ and Khadro have intraformational seals. The Lower Ranikot covers both Pab and Khadro formations (Fig. 2b) and considered as finest seal. However, the Pab Formation is sandy and may poorly act as a seal due to sand-body interconnectivity, whereas in some areas of South it underlies the Khadro Formation which may act as an appropriate seal. The Khadro Formation contains a rather poor intraformational seal but base of the formation may act an effective seal at underlying horizons, but internal mudstones are not very thick or laterally extensive. The overlying Lower Ranikot has a good basal muddy horizon in some areas where it acts as a seal rock for the Pab/Khadro formations. Moreover, in same region sandstones at the base of the Ranikot Formation are good reservoir which may be migrated upper sandy part of the Ranikot Formation and intraformational shale would acts as seal for migrating hydrocarbon.

\section{Results and discussion}

Subsurface stratigraphic and structural traps are possibly occurred in the study area. However, seismic data in conjunction with surface geology were interpreted to establish the structural styles which are very important for the exploration of hydrocarbons.

\section{Seismic interpretation}

Seismic signatures, continuous, parallel reflectors of medium and high amplitude are marked throughout the section from 400 to $3400 \mathrm{~ms}$ that covered mainly by the Eocene and the Pliocene strata (Figs. 4a-d, 5a-d). These reflectors are almost smooth and parallel except the fault planes where they show the distortions. These distortions are also helpful in defining different faults along the seismic sections.

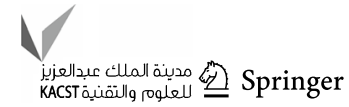




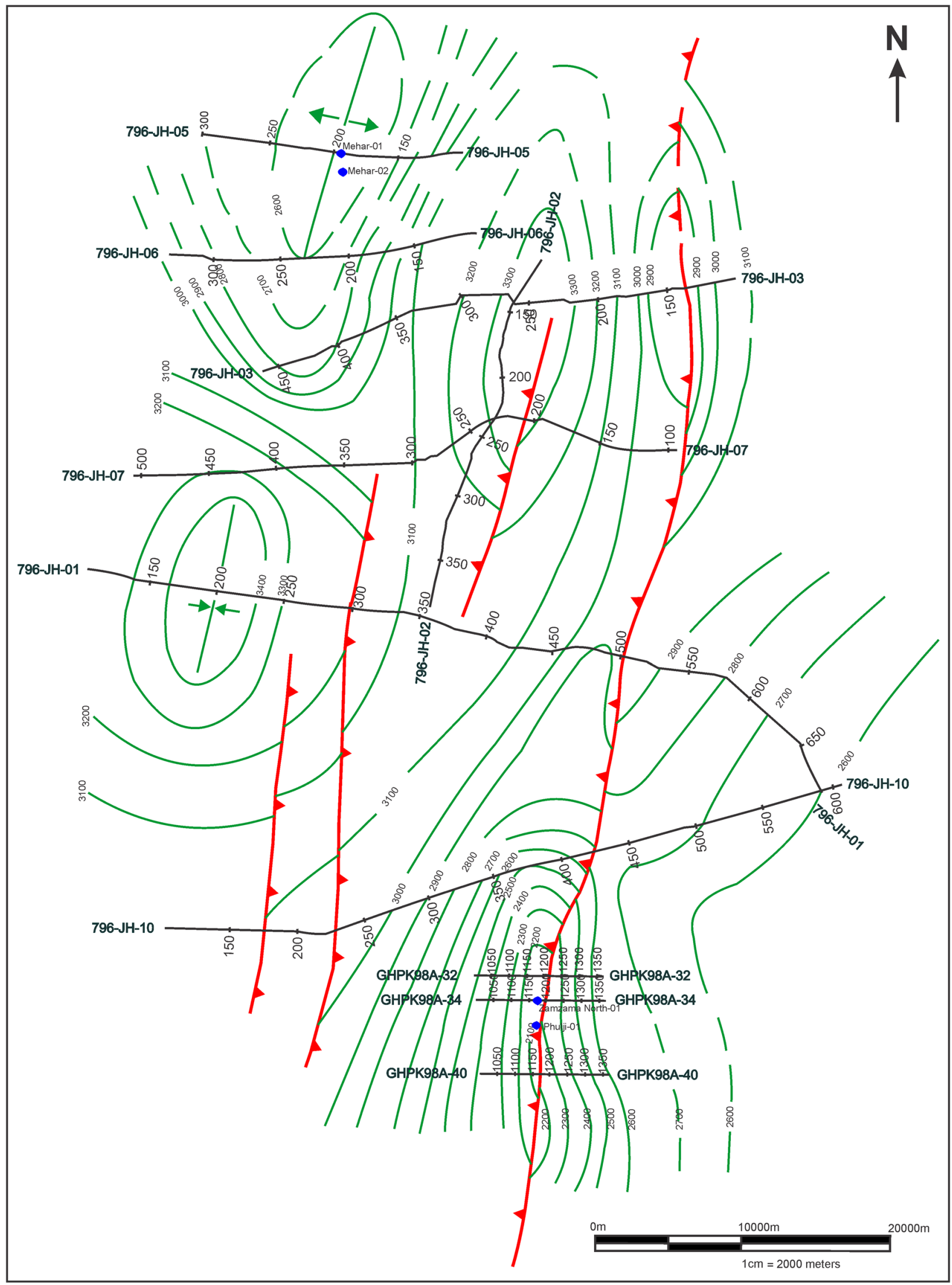


4Fig. 3 Structure contours map on top of Pab Formation, Zamzama gas field, Southern Indus Basin, Pakistan. Red lines indicate the faults, blue shows the contours, and black lines show the seismic lines

Conversely, sections below $2800 \mathrm{~ms}$ reveal discontinuous, semi-parallel reflectors of medium and high amplitude and low frequency. However, above $2800 \mathrm{~ms}$ time range it delivers a hint to define decollement.

The seismic section depicts two prominent structures i.e. Zamzama in South and Mehar in North of study area. Zamzama Structure relatively shallower than Mehar Structure but both are separated by a broad syncline. Seismic sections show that investigated area comprises of North-South orientated anticlines (Fig. 4d), deformed by westward dipping thrust faults having throw of more than a hundred meter near the core of structure (Figs. 5b-d). Moreover, two minor faults (thrust and back thrust) having throw of few meters are also present on the western side of the hanging wall (Figs. 5b-d). Shale of the Cretaceous age seems to be provided the decollement for these reverse faults. Seismic section also suggests some normal paleo-faults of rifting time below the Chiltan Formation (Fig. 5a). The base of the Tertiary reflector indicates unconformity, which is easily recognizable in the structure of eastern side (Figs. 4d, 5a-d). However, in West unconformity is not easily identified due to associated compressional faulting and distortion of the seismic character. Deccan volcanoes also distort the picking of the reflector due to its high amplitude and lateral extent. The Tertiary base is taken as a base reflector in this area due to high amplitude unit.

Pab Formation is generally thin around the Zamzama area and is eroded by unconformity in the base of the Tertiary (Figs. 5b-d). It is picked around Zamzama above a high amplitude reflector (Figs. 4a, c, d, 5a) and appears to be conformable with the underlying units apart from where it is thrusted out.

The top of the Chiltan Formation is generally picked along a high amplitude reflector, and around Zamzama area it is overlain by horizons of less continuity and lower amplitude. In North however, the horizon is picked along a semicontinuous high amplitude reflector within a low amplitude homogenous zone with high amplitude continuous reflects above and below (Figs. $4 \mathrm{a}-\mathrm{d}, 5 \mathrm{a}-\mathrm{d}$ ). This is due the unconformable nature of the horizon.

\section{Structural model}

Structure was also interpreted by generating three east-west oriented seismic sections. (796-JH-03; Fig. 6a, 796-JH-10; Fig. 6b, 796-JH-01; Fig. 6c) by using the interval velocities passing along Zamzama North structure. The structural interpretation shows undisturbed sequence down to the
Late Triassic by normal faulting or extensional tectonics (Figs. 6a, b).

Jurassic fault trends throughout the Southern Indus Basin are generally orientated NNW-SSE (Fig. 6b). Strike-slip behavior is noted along some of these NNW-SSE trending Jurassic and Cretaceous faults in those areas which are close to the fold belt. Tertiary strike-slip faulting reactivates Jurassic faults (Ahmed et al. 1992; Quad and Quadri 1996). The Jaisalmer area of the Southern Indus Basin, Rajasthan India and extends across the border into Pakistan to the Mari and Sui gas fields, is controlled by strike-slip tectonics (Sharma 2006) that initiated in the Jurassic. The Late Jurassic and Cretaceous seem to be time of normal faulting along the west coast of the Indian Plate, with $\sim \mathrm{N}-\mathrm{S}$ trending rift systems in the region (Fig. 6b).

The Cretaceous faults in the Southern Indus Basin trend dominantly NNW-SSE and have previously been attributed to a failed Cretaceous to Paleocene rifting episode (Figs. 6b, c). Seismic data suggest, however, that these faults developed around the Cretaceous-Tertiary boundary. Many faults stop at the base of Tertiary unconformity, but a small number of them extend upward at the base of Tertiary. Additionally, majority of them show the characteristics of normal and transtentional structures (Figs. 6b, c). Similar normal faults (horst and graben structures) described by Wasimuddin et al. (2005) in Thar platform area of Southern Indus Basin.

The study area appears to be deformed by sinistral tectonism, happened between the Indian and the Eurasian plates, probably producing reversal of the earlier sequences by the Paleocene, with obduction of the Bela ophiolite. It is probable that gentle folding in the area was related to this emplacement event. Aitchison et al. (2007) suggested main contraction in the middle Miocene which is the result of continent-continent collision between Indian and Eurasian plates, which is clarify the present interpretation (Figs. 4b-d, $5 \mathrm{a}, \mathrm{b})$. The immediate effects of this Oligocene to Recent contraction were most strongly occurred close to the margins of the Kirthar and Sulaiman Fold Belts (Ahmed et al. 1992). Present interpretation shows that the area is deformed by the transpression in passive roof thrust duplex fashion (Figs. 6a-c) and reactivation of previously normal Mesozoic faults as high-angle reverse faults possibly a feature of the fold belt which is thrusted over thick, dip gently the molasses within the Kirthar Foredeep. Regional geo-seismic model (Figs. 6a-c) shows that fold-thrust structure has developed along with transpressive tectonics. The folding, thrusting, and development of passive roof thrust-related structure in the frontal foldbelt, seems to be late Tertiary in age. The rocks are deformed by the transpression with very low intensity in the eastern part of study area and anticlines are developed in the post Triassic rocks through some strike-slip faulting. To the west, passive back thrust duplex geometry is developed, the roof thrust run in Cretaceous while floor

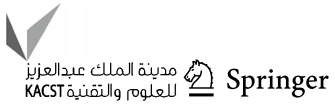




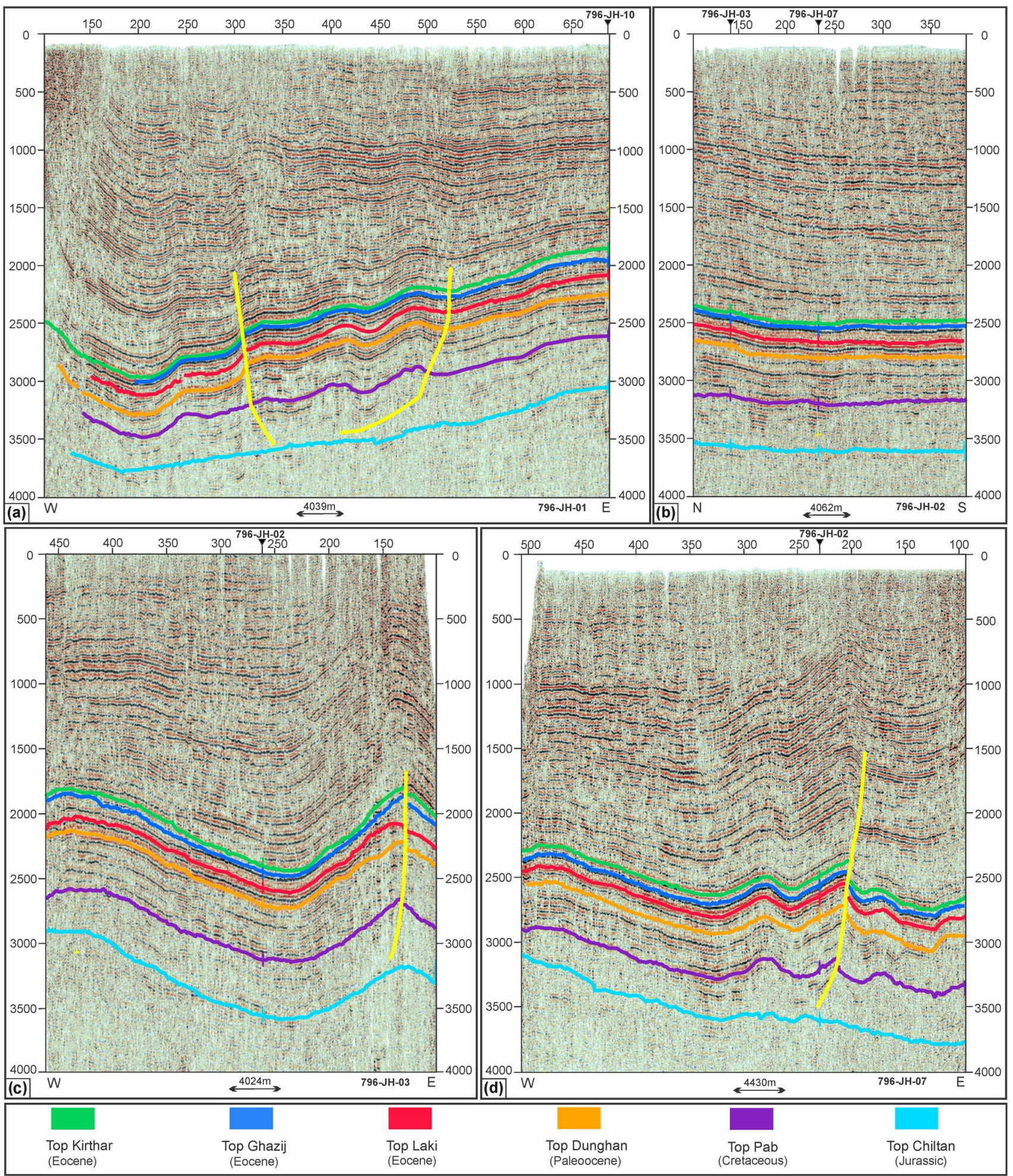

Fig. 4 shows the six prominent marked reflectors on the seismic cross section, Zamzama gas field, Southern Indus Basin, Pakistan. a Seismic line 796-JH-01 shows the horse structure. b Seismic line 796-JH-
02 exhibits the continuous reflectors. c Seismic line 796-JH-03 displays a fault on the eastern side of the cross section. d Seismic line 796-JH-07 shows the normal fault 

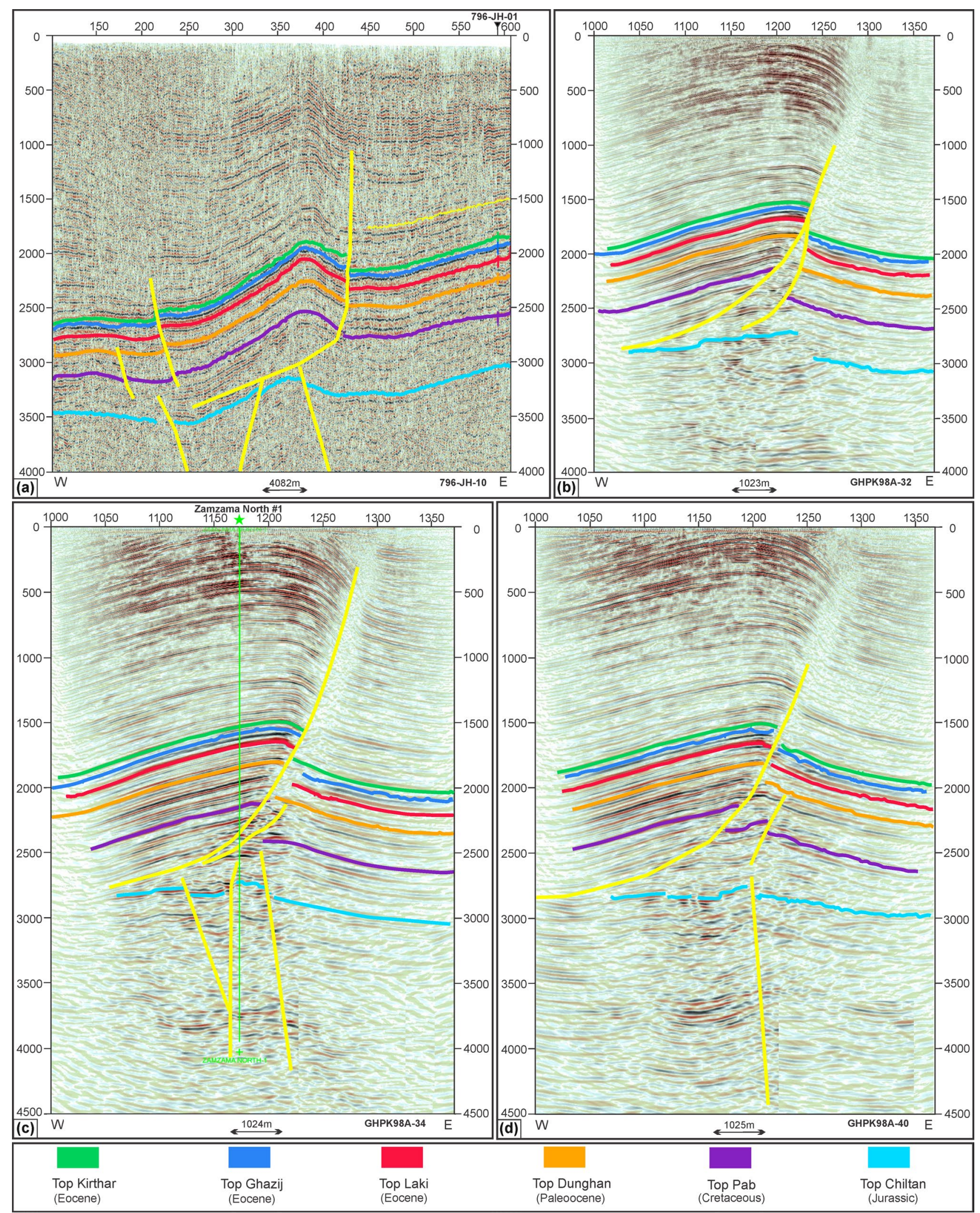

Fig. 5 The six prominent marked reflectors on the seismic cross section, Zamzama gas field, Southern Indus Basin, Pakistan. a Seismic line 796-JH-10 displays the extension of fault into Jurassic strata. b Seismic line GHPK-98A-32 shows a major fault along with minor fault. c Seismic Line GHPK-98A-34 exhibits the presence of major and minor faults in the entire strata. d Seismic line GHPK-98A-40 shows the two faults that run into Jurassic strata 

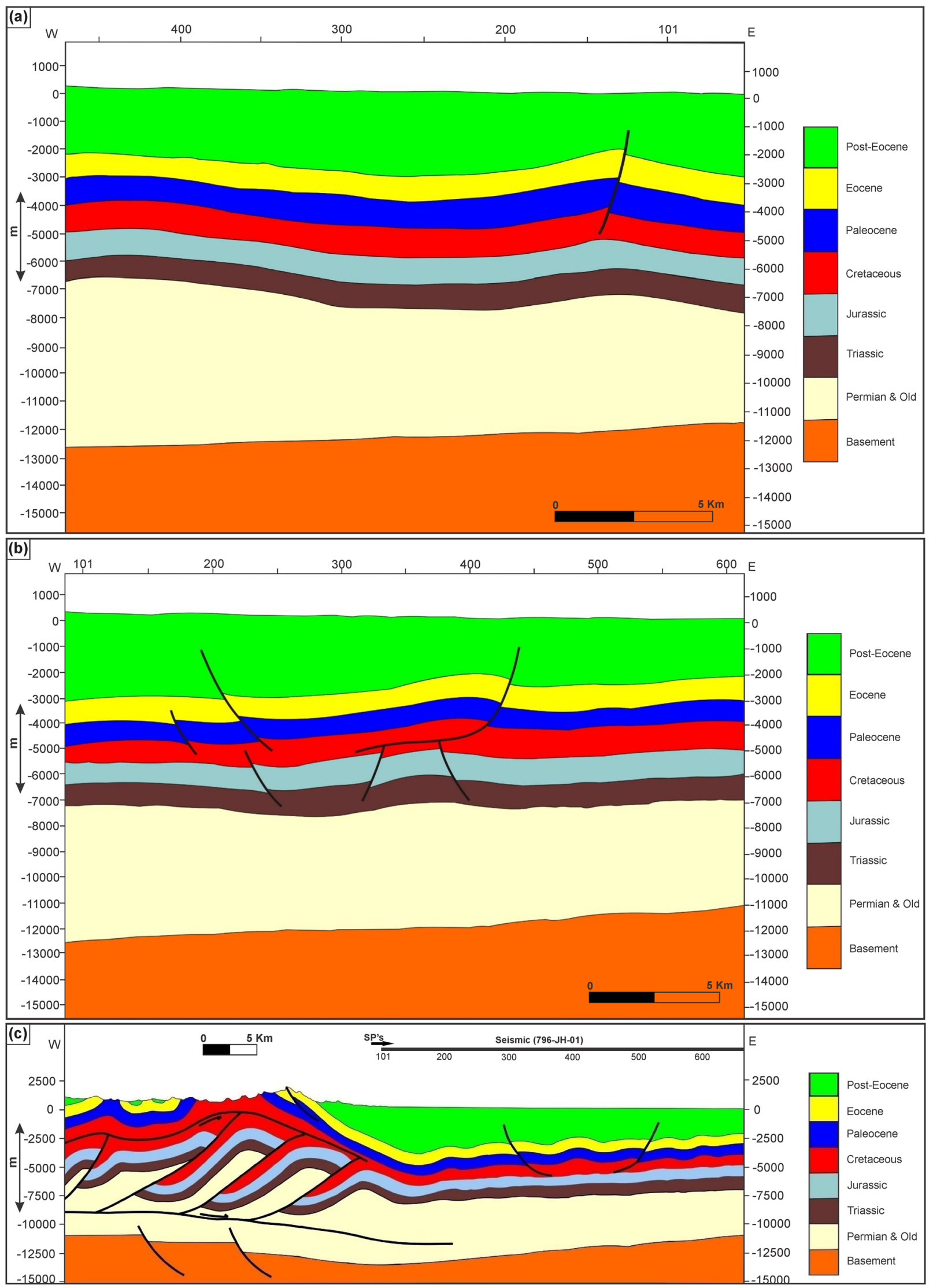
4Fig. 6 a Geo-seismic model along seismic line 796-JH-03 that shows the penetration of fault into cretaceous sediments. b Geo-seismic model along seismic line 796-JH-10 that form pop-up structure. c Geo-seismic model along the seismic line 796-JH-01 that displays the normal and extensional faults

thrust lying in the Permian/older rocks (Fig. 6c). Horses between the roof and floor thrusts are the suitable features having the $>5 \mathrm{~km}$ width and may be provide trapping geometries for the accumulation of hydrocarbons.

\section{Conclusions}

The stratigraphy and structural deformation favours the effective petroleum system in area as revealed by this study and which is proven by the presence of discoveries in the area. The seismic structure indicates a $4 \mathrm{~km}$ wide north anticline that intercepted by a well-developed reverse fault in the south of study area, whereas northern anticline of the area depicting a low or synclinal area that gets deeper trends toward west. Seismic cross sections also depict the apparently normal faults that stop at or near the base of Tertiary unconformity with very low throw which clarify their occurrence before the deposition of the Tertiary base. Geoseismic model shows the evidences of deformation due to transpression with very low intensity in the eastern part of study area, and anticlines are developed in the post Triassic rocks through some strike-slip faulting. To the west passive back thrust duplex geometry is developed, the roof thrust run in Cretaceous while floor thrust lying in the Permian/ older rocks. These thrusts are the suitable features that provide trapping geometries for the accumulation of hydrocarbons. Furthermore, study area fulfils all requirements for the accumulation of hydrocarbon. The uppermost Cretaceous Pab Formation represents a significant reservoir rock. Sember and Goru formations are the main source rocks which exhibit high ratio of waxy pristane/phytane that indicate main source of oil generation. Moreover, upper part of the Pab, the Khadro, and the Ranikot formations, acting as a cap rock in the Zamzama field.

Acknowledgement The authors are grateful to the Director General, Petroleum Concessions (DGPC), Pakistan, for the provision of data for this research work. The authors are thankful to Editor-in-Chief Dr. Turgay Ertekin and the anonymous reviewers, for their useful comments to improve the quality of the paper.

Author contributions All the authors actively participated in preparation of the manuscript at all stages. MAQ, SG, and MR participated in drafting the manuscript. MAQ, MR, and SA wrote the main text and prepared figures of the manuscript.
Funding The present work is financially supported by University of the Punjab, Lahore, Pakistan, and Oil and Gas Development Company Limited (OGDCL), Islamabad, Pakistan.

Availability of data and material All relevant data and material are presented in the main paper.

\section{Compliance with ethical standards}

Conflict of interest The authors declare that they have no conflict of interest.

Open Access This article is licensed under a Creative Commons Attribution 4.0 International License, which permits use, sharing, adaptation, distribution and reproduction in any medium or format, as long as you give appropriate credit to the original author(s) and the source, provide a link to the Creative Commons licence, and indicate if changes were made. The images or other third party material in this article are included in the article's Creative Commons licence, unless indicated otherwise in a credit line to the material. If material is not included in the article's Creative Commons licence and your intended use is not permitted by statutory regulation or exceeds the permitted use, you will need to obtain permission directly from the copyright holder. To view a copy of this licence, visit http://creativecommons.org/licenses/by/4.0/.

\section{References}

Abbasi SA, Asim S, Solangi SH, Khan F (2016) Study of fault configuration related mysteries through multi seismic attribute analysis technique in Zamzama gas field area, southern Indus Basin Pakistan. Geod Geodyn 7(2):132-142

Abid M, Riaz M, Shah M, Zafar T, Malik A (2019) Structural interpretation and reservoir characterization of the Missa Keswal area, upper Indus basin Pakistan. B Geofis Teor Appl 60(3):419-432

Abid M, Riaz M, Zafar T, Asif M, Shakir U (2020) Integrated approach for Reservoir characterization and Field development of Meyal area, Upper Indus basin Pakistan. Indian J Geo-Mar Sci 49(4):678-685

Ahmed R, Ali SM, Ahmed J (1992) Structural styles and hydrocarbon prospects of Sibi Foreland Basin Pakistan. Pakistan J Hydrocarbon Res 4(1):31-40

Aitchison JC, Ali JR, Davis AM (2007) When and where did India and Asia collide? J Geophys Res Solid Earth 112:1-19

Blair TC, McPherson JG (1994) Historical adjustments by Walker River to lake-level fall over a tectonically tilted half-graben floor, Walker Lake Basin. Nevada Sediment Geol 92(1-2):7-16

Ghazi S, Aziz T, Khalid P, Sahraeyan M (2014) Petroleum play analysis of the jurassic sequence, meyal-field, Potwar Basin Pakistan. J Geol Soc India 84(6):727-738

Grelund S, Sassi W, Lamotte DF, Jaswal T, Roure F (2002) Kinematics of eastern salt range and Southern Potwar Basin (Pakistan): a new scenario. Mar Petrol Geol 19:1127-1139

Jackson MA, Jellis RG, Hill R, Roberson P, Woodall MA, Wormald G, Jafri N (2004) Zamzama gas field-balancing risk and value. In: SPE Asia Pacific Oil and Gas Conference, Perth, Australia, October 18-20. SPE88577

Jamil A, Waheed A, Sheikh RA (2012) Pakistan's major petroleum plays. An overview of dwindling reserves. Search Discovery 10399:1-2

Jaume SC, Lillie RJ (1988) Mechanics of the salt range-potwar plateau, Pakistan: a fold and thrust belt underlain by evaporates. Tectonics 7:57-71 
Meissner JrC, Rahman H (1973) Distribution, thickness, and Lithology of Paleocene Rocks in Pakistan. In: USGS Professional Paper 716-E, US Government Office, Washington.

Kadri IB (1993) Cretaceous source rocks in Pakistan. In: AAPG/SVG International Conference and Exhibitions, Vanezuela.

Kadri IB (1995) Petroleum geology of Pakistan. Pakistan Petroleum Limited, Karachi, p 275

Kazmi AH, Abbasi AI (2008) Stratigraphy and historical geology of Pakistan. Peshawar Publication, Peshawar, pp 181-185

Kazmi AH, Jan MQ (1997) Graphic geology and tectonic of Pakistan. Graphic Publishers, Karachi, p 528

Kazmi AH, Rana RA (1982) Tectonic map of Pakistan. Geol Surv Pakistan 39:283-300

Kemal A (1991) Geology and new trends for petroleum exploration in Pakistan. In: Ahmed G, Kemal A, Zaman ASH, Humayon M (eds) New directions and strategies for accelerating petroleum exploration and production in Pakistan. Ministry of Petroleum and Natural Resources, Pakistan, pp 16-57

Lillie RJ, Johnson GD, Yousuf M, Zamin ASH, Yeats RS (1987) Structural development within the Himalayan foreland basin fold-andthrust belt in northern Pakistan. In: Beaumont C, Tankard AJ (eds.) Sedimentary basins and basin forming mechanisms. Canadian Society of Petroleum Geologists Memoir, 379-392.

Moghal MA, Hameed A, Saqi MI, Bugti MN (2007) Subsurface geometry of Potwar Sub Basin in relation to structuration and entrapment Pakistan. J Hydrocarbon Res 17:61-72

Pennock ES, Lillie RJ, Zaman ASH, Yousaf M (1989) Structural interpretation of seismic reflection data from eastern Salt Range and Potwar Plateau Pakistan. Am Assoc Pet Geol Bull 73(7):841-857

Powell CM (1979) A speculative tectonic history of Pakistan and surroundings: Some constraints from the Indian Ocean. In: Farah A, DeJong KA (eds) Geodynamics of Pakistan. Geological Survey of Pakistan, Pakistan, pp 5-24

Quadri V, Quadri SMGJ (1996) Anatomy of success in oil and gas exploration in Pakistan. Oil Gas J 94(20):1-20

Quadri VN, Quadri SMJG (1998) Pakistan has unventured regions, untested plays. Oil Gas J Archive 96(12). http://ogj.pennwellne t.com. Accessed 3 Feb 2000

Reading HG (1996) Sedimentary environments: processes. Blackwell Scientific Publications, Facies and Stratigraphy, p 688
Riaz M, Pimentel N, Ghazi S, Zafar T, Alam A, Ariser S (2018) Lithostratigraphic analysis of the Eocene reservoir units of Meyal Area, Potwar Basin Pakistan. Himal Geol 39(2):72-81

Riaz M, Pimentel N, Zafar T, Ghazi S (2019) 2D Seismic Interpretation of Meyal Area, Northern Potwar deform zone (NPDZ), Potwar Basin, Pakistan. Open Geosci 11:1-16

Shah SMI (1977) Stratigraphy of Pakistan. Geological survey of Pakistan 12:138

Shah SMI (2009) Stratigraphy of Pakistan. Geological survey of Pakistan, pp 400

Sharma AK (2006) Quantitative stratigraphic inversion. Doctoral dissertation, Virginia Polytechnic Institute and State University: Virginia.

Siddiqui NK (1992) Sui main limestone, regional geology and pressure analysis of a closed system reservoir. In: First South-Asia Geological Congress (GEOSAS-1), February 23-27, Islamabad Pakistan.

Siddiqui NK, Khan MR (1992) Eocene carbonate development, lower Indus Basin, Pakistan. In: First South-Asia Geological Congress (GEOSAS-1) February 23-27, Islamabad Pakistan.

Treloar PJ, Coward MP, Chambers AF, Izatt CN, Jackson KC (1992) Thrust geometries, interferences, and rotations in the northwest Himalaya. In: McClay KR (ed) Thrust tectonics. Chapman and Hall, London, pp 325-342

Wasimuddin M, Jadoon IAK, Weihua W, Ebdon CC, Akhter S (2005) Integration of the Image Logs in the Structural Analysis of the Zaur Field, Pakistan. PAPG/SPE annual technical conference. Islamabad, Pakistan, pp 61-79

Zafar ZA, Shoaib K, Afsar F, Raja ZA, Tanveer A, Burley SD (2018) $A$ radical seismic interpretation re-think resolves the structural complexities of the Zamzama Field, Kirther Foredeep, Pakistan. PAPG/SPE annual technical conference, December. Islamabad, Pakistan, pp 11-12

Publisher's Note Springer Nature remains neutral with regard to jurisdictional claims in published maps and institutional affiliations. 